\title{
CTSA APPROACH IN EDUCATION: OPPORTUNITIES AND CHALLENGES IN CONTINUING EDUCATION TEACHERS
}

\author{
M. C. FIGUEIREDO*, Z. F. D. C. ROCHA e A. DUTRA
Universidade Tecnológica Federal do Paraná, Campus Londrina
marciafigueired@utfpr.edu.br* \\ Article submitted in October/2015 and accepted in February/2016 \\ DOI: $10.15628 /$ holos.2016.3522
}

\section{ABSTRACT}

In order to initiate the formation of critical citizens from the Basic Education, this research aimed to investigate how a group of teachers from the local public from Londrina in Parana conceives of Science-TechnologySociety-Environment Approach (CTSA) for the teaching of scientific content. Data were collected through questionnaires and speeches from the participating during a course entitled Science-Technology-Society, offered in the course of Specialization in Education and Technology of the Federal Technological University of Paraná, Brazil. According to the data obtained initially unaware of this entire group approach to teaching. Soon,
\end{abstract}

they were not as elaborate, plan and develop scientific content prioritizing CTSA relations. Therefore, this research promoted participants the innovation pedagogical and methodological knowledge to work the CTSA relationships in the classroom, because teachers revealed in his speeches understanding of how important it is to develop the contents prioritizing CTSA relations to form citizens critical to society. Based on these data, we stress the importance of teaching continuing education that enables the study of the CTSA approach to mobilize a more qualitative basic education.

KEYWORDS: Basic education, civic education, interdisciplinary teaching, CTSA, teaching. 


\section{INTRODUCTION}

The continuous quest for improvement of science teaching, from the knowledge approached in classroom, is an endless concern, once for fulfilling the main objective of graduating critical citizens, it is necessary to develop pedagogical and methodological proposals that have as a goal the meaningful learning, so that students can make, from the studied knowledge, decisions in face of situations that may occur either in the society they live in and in the world likewise.

However, many teachers, who work at the primary education, find it difficult to stimulate teaching and learning situations that promote the graduation of the critical-reflective citizen. Therefore, continuing education is a challenge to be achieved and one of the alternatives to attain that is through the Science-Technology-Society-Environment perspective (STSE), since it "[...] focuses on the development of the decision making capacity through an approach that inter-relates science, technology and society, conceiving the former as a social-historical process, and not dogmatic" (SANTOS, SCHNETZLER, 2010, p. 79-80).

The critical- reflective graduation of the citizen is one of the main concerns of basic education, as per the Brazilian Law of Guidelines and Bases for the National Education (LDB 9394/96), Article 22, which prescribes "[...] improve the student, assuring him an indispensable common graduation for the citizenship, providing him the means to progress at work and in later studies" (BRAZIL, 2010, p. 20).

The STSE studies have encompassed several multidisciplinary programs that focus on social relations between science and technology, sharing "(a) the rejection of the image of science as a pure activity; (b) the critics of the conception of technology as applied and neutral science; and (c) condemnation of technocracy" (CEREZO, 2002, p. 9).

In the scientific literature, there are several studies with the STSE theme, among which we highlight the research Solbes and Vilches (2004), Ricardo (2007), Marcondes et al., (2009), Menezes et al., (2012). There are still theoretical reflections from investigations that characterize the perspective Science Technology and Society (STS), as well as empirical studies, which work the STSE relations. For example, the book entitled "STS and scientific education: challenges, trends and research findings", written by the Ibero American authors and organized by Auler and Santos (2011), during the II Ibero-American Seminar Science-Technology-Society. In this work, there are several contributions to undergraduate and postgraduate students, basic and higher education professors, scientific education researchers, and professionals from other, fields keen on this line of study, likewise.

Thus, the higher education institutions, for example, may provide spaces for initial and continuing professor's training in order to get time for studying, researching and reflecting about their pedagogical practice to develop personal or collective actions, which promote more qualitative education.

In this context, this current study aimed to investigate the conceptions of science and technology of professors from different areas of knowledge, who have been involved in basic education in order to check whether they knew the STSE approach to the teaching and whether 
they found it difficult to work out their relations, and developing scientific content likewise, based on this perspective.

\section{THE BEGINNING OF THE STS/STSE MOVEMENT IN THE WORLD}

Science and technology have been endeavoring for empowerment since World War II, demanding either social or political unrestrained support, being backed by an optimist period of possibilities, which is remarkable for

[...] the first electronic computers (ENIAC, 1946); the first organ transplantation (kidneys, 1950); the first application of atomic energy in transportation (USS Nautilus, 1954), and even the conception of birth control pills (1955) (BAZZO, LINSINGEN, PEREIRA, 2003, p. 121).

However, writers elucidate that the world has also been experiencing many failures directly associated to science and technology, including: contaminant waste, atomic accidents with reactors of military and civil transportations, poisoning caused by pharmaceutical drugs, lacking of oil, among others.

These several events have started a social, political and educational dilemma in United States and other western countries, as noticed at the launching of the first artificial satellite by URSS in 1957: The Sputnik I. In that same year, there was an accident involving the Windscale atomic reactor as well as cases of congenital disorders in 1961 caused by the use of thalidomide in Europe and subdeveloped countries (BAZZO, LINSINGEN, PEREIRA, 2003).

For these authors, including Garcia, Cerezo and Luján (1996), debates about the interactions between science and technology got enhanced in 1962, when Silent Spring, written by the naturalist and biologist Rachel Carson, was released, mostly getting attention for environmental harm caused by pesticides as DDT. Also in that year, The Structure of Scientific Revolutions, released by Thomas Kuhn, "[...] marked a starting point for a new perception over science and a new way of thinking science. Then, it has established an alternative global conception for the classic way of working with science" (BAZZO, 1998, p. 165).

From this point, Kuhn's conception allows, through his theories, to "[...] approach both science and technology in a different way from the standard actual for centuries, because it fights against confirmationist paradigms [...]" then elaborated (BAZZO, 1998, p. 166).

Faced with these events, people started to evaluate the benefits and drawbacks regarding scientific and technological development, emerging doubts and concerns that have contributed to a change of mindset, aiming a process that gradually came to reveal that,

When subjects of science and technology such as ethics, noninterference, application and susceptibility are related to infamous political issues, they challenge the old paradigm about human developing linearly associated with the concept of scientific and technological development (BAZZO, 1998, p. 147). 
It was in this period that the real understanding of essentialism and triumphalism permeating science and technology has been settled. Whereas this concept points out for a linear model of development, that is:

Linear model of development: country's welfare depends on funding basic science and on the development of technology with noninterference, as well as on the need of keeping science's empowerment, in order to grant the success of the model. Economic growth and social development would happen as a consequence (BAZZO, LINSINGEN, PEREIRA, 2003, p. 121-122).

It is important to people understand that "science is not neutral and its development is directly interwoven with social, political, economic, cultural and environmental aspects" (SANTOS, MORTIMER, 2001, p. 2).

Thus, people need to know how science contents are related to inherent issues of Science and Technology that can impact environment in either positive or negative ways and, in consequence, impact society. Keeping that in mind, people may take well-based decisions when dealing with some questions, because "[...] science is not only for scientists and its matters strongly affect society. Therefore, it demands a social oversight what, under a democratic perspective, means to involve an increasingly greater part of population when making decisions about Science and Technology" (SANTOS, MORTIMER, 2001, p. 2).

According to the researchers, it is crucial for society to realize the political and economic interests that set the rules for science and technology, so people will be able to contribute and deliberate about benefits and drawbacks that are to be settled in people's every day and in environment.

Throughout the intense dilemmas regarding social, scientific and technological development, great part of society started to think and has figured out how simplistic their ideas were when compared to this model, because science and technology, despite their contributions to improve our lives, also contribute to the raise of social inequality and bring consequences for nature.

In spite of the negative events occurred in World War II, it was only in 1960, in USA, that "[...] the first steps were taken to perform interdisciplinary researches in order to better understand the relationships between science, technology and society, also known as STS (science, technology and society) in that time" (BAZZO, 1998, p. 210).

STS movement has required from science and technology a positioning in order to clarify the idea that science and technology would be able to solve environmental, social and economic problems (AULER, 2002). Given these aspects, Gouvêa and Leal (2001, p. 70) describe the evolution of the expression "STS movement":

By tracing a timeline about the educational movement in STS, it becomes clear that it began in Great Britain in late 1960s - early 1970s, and developed itself until the 1980 s through debates of ideas and values until it started to contemplate practical issues regarding resources, teachers, texts, resumes and evaluation processes. It was when it finally became the movement with the goal to develop education based on several ways to educate in STS for different scholar grades in 1990 s. 
The great impact of STS is related to its conception that adverse to the classical perception over science and technology around the world, employing great emphasis in compulsory and higher education fields, which tried to integrate Science-Technology-Society for a better comprehension about its implications (VON LINSIGEN, 2007).

This changing of perception over science and technology got enhanced at academic and educative sectors in 1970s and got bold until the present day through STS researches (CEREZO, 2002).

Other countries (Canada, England, Netherlands and Germany), in the same way, has begun to work on educational sector with possibilities of pedagogical focus to understand the facts related to science and technology, as Bazzo (1998) highlights. According to him, in parallel with the STS programs, the 1970s have also been remarkable by actions involving groups annoyed with the ecological consequences, what, in that time, have contributed with the rise of governmental agencies worried about protecting environment.

Cerezo (2002) explains that there can be found two great STS traditional lines of research. The first one is the European, which tries to understand the social contextualization of science and technology development. Therefore, it mostly heads to the academic researching knowledge. The second line, originated in USA and more activist, "[...] has focused further on social and environmental consequences of technological artifacts, generally not considering the social history of the products" (CEREZO, 2002, p.8).

Given these two traditional lines, Bazzo (1998, p. 221-222) summarizes some differences that have emerged between them, in order to ease their understanding:

European tradition [...] has promoted the focus on prior social factors; it has mainly given attention to science over technology; it has assumed [...] a theoretical and descriptive status; and its explaining mark has been set on social sciences sociology, psychology, anthropology. American tradition [...] has always given focus on the social consequences of science and technology; [...] it has mostly given attention to technology over science; [...] its evaluation mark is related to ethics, educational theory and other subjects.

Nevertheless, those differences were only relevant during the first two decades of STS researches, because, according to García, Cerezo and Luján (1996), in spite of the cooperation attempts between the two traditions, both follow with their own proceedings, congresses, symposiums, journals, associations.

\subsection{The beginning of STS/STSA movement in education}

According to Cerezo (2002), Bazzo, Von Linsingen and Pereira (2003), STS programs and researches have been developed in three sectors: the first one, which comprehends researching, offers as alternative to provide the academic community a revising about science and technology classical perception; the second one comprehends the public political sector, which aims the public inclusion and oversight through alternatives that help people's decisions; finally, the third one 
comprehends education, which, in the last years, has been getting stronger in STS programs and materials, both in compulsory and higher education in many countries.

However, according to Von Linsingen (2007), only in the last 20 years this movement got relevance in Brazil. For Santos and Schnetzler (2010, p. 57), its mark was in 1990, with the "[...] Global Conference about Science Education for the $21^{\text {st }}$ Century: AST - Alphabetization in science and technology", whose main subject was the scientific education of the citizens.

Discussions and indications about the relevance in teaching science in order to endorse the development of citizenship awareness can be found in articles written a few years before the 1990s in Brazil. For example, "Teaching Science for Embracing Social Responsibilities by Krasilchik (1985) and "Science teaching and the citizenship education" written by the same author and released in 1988.

Thereby, STS researching is extended to Post-Graduation Programs in Science education, in which there can be found several researches such as the ones performed by Auler (2002), Silva (2003), Vasconcellos (2008), Nunes (2010), Strieder (2012), Akahoshi (2012), and others.

It's important to underline that some Brazilian institutions have been endeavoring and developing STS researches, as well as the performed at "[...] Universidade Estadual de Campinas (UNICAMP), at Universidade Federal de Santa Catarina (UFSC), at Universidade Federal do Rio de Janeiro (UFRJ) and at Universidade de Brasília (UnB) [...]" (VON LINSINGEN, 2007, p. 10). In this parameter, Santos and Schnetzler (2010, p. 57) state:

There was the assembling of "Grupo de Trabalho de CTS" at Associação Brasileira de Pesquisa e Educação em Ciências in 2000s and the release of many articles about this subject in journals about education of science, from which six articles releasing about STS in a special edition of Ciência $e$ Educação (Science and Education) (tom. 7, ed. 2, 2002) and the special number of the journal Ciência \& Ensino dedicated to STS can be featured (tom. 1, special ed., 2007).

Nowadays, researches in STS are getting more extensive and relevant with support and cooperation of other countries. For example, an important period of debates, conferences, lectures, roundtables and work presentations happened in Brasilia, Brazil, at II Seminário Ibero-Americano CTS no Ensino das Ciências (II SIACTS-EC), in 2010 July.

An important question that was present in discussions at II SIACTC-EC was if the letter E (Environment) would be inserted in STS, transforming it in STSE. According to Vilches and Pérez (2010, p. 3), they have argued that it's highly relevant incorporating the letter E to STS because, “[...] the ones who promote the expression STSE are not saying that E isn't contained in STS, but, their goal is to give more emphasis on the increasing of scientific education, aiming a misdealing with environmental issues, even when STS relationships are incorporated".

Furthermore, these authors state that, considering the natural problems present in environment that are getting more intense because of the human intervention, it is necessary to incorporate the environmental issues into STS focus. 
As stated by Vasconcellos and Santos (2008, p. 3), "assuming that environmental problems are caused by exhaustion on nature by humans, some authors have started to incorporate environmental issues into STS focus, starting to use the acronym". In this regard, authors say:

The environmental issue is a concerning increasingly more present in the whole society and is a reality that human being needs to be familiarized in terms. That provokes the need for a specific education for this matter, which may help to develop awareness on people that want to preserve live on planet Earth and better social conditions for human existence (VASCONCELLOS, SANTOS, 2008, p. 3).

Given the problems reported about the environmental issue, Aikenhead (2003) explains and states that the acronym STSE is an outcome from STS (Science - Technology - Society) movement, observing environmental aspects; therefore it is necessary to incorporate the letter $\mathrm{E}$.

There are several essays developed under STSE focus in literary works. Some of them can be reported, as Tenreiro-Vieira and Vieira, (2005), Solbes and Rios (2007), Muenchen and Auler (2007), Firme and Amaral (2008), Chrispino et al. (2013), and others.

It is important to consider the consequences that science and technology have caused and echoed around the world, what assumes consequences (global warming, misery, ozone depletion, floods, and extinction crisis, marine and fluvial pollution) in humankind every day.

Considering the researches performed by Vilches and Pérez (2010), it's necessary to bold the importance of letter E, for Environment, to the term STS, which turns into STSE, because when only Science-Technology-Society (STS) is read, there's a risk of non-comprehension that environmental issues are included. Furthermore, when Science-Technology-Society-Environment (STSE) is read, it is more assured that environmental issues will be approached on science education. Therefore, in this research, it was also contemplated the use of the term Science-TechnologySociety-Environment (STSE) in order to grant that the environment will indeed be considered in the development of scientific contents.

\subsubsection{STSE approach in in-service programs for teachers}

Many of the scientific contents that are studied at the classroom have been developed through "contents" transmission, what hasn't contributed much with individual citizenship education. Because, generally, it becomes "relevant" only for those who are going to apply for the Exame Nacional do Ensino Médio (ENEM) as a way to enter the college at Brazilian public universities through SiSU (Sistema de Seleção Unificada), and also for those who will try an opportunity through the vestibular.

This way of getting information can be easily performed by students through internet websites like Google. To perform a paradigm changing in educational context, education must contribute to the citizenship formation of the student. Therefore, the student needs to make part of the process of education and learning in a way that he will understand how the class content is a part of his day-by-day, so he will be able to make decisions. 
In order to make it a reality, LDB also pictures in its article 35 that the final step of compulsory education, that is, the High School, with minimum duration of three years, must give emphasis in its curriculum to "[...] a basic education of technology, the understanding of science, languages and arts signification; the historical process of culture and science development; the Portuguese language as an instrument of communication, access to knowledge and citizenship exercising" (BRASIL, 2010, p. 29).

To reach this goal, it's important to agree a group commitment, involving all people who work in educational field. As a consequence, an alternative to dismiss the merely technical learning in compulsory education would be through a STSE approach. Because it's committed with scientific education contemplating people, in order to "[...] bring for students a knowledge that leads them to be active people in modern society, looking for alternatives for science and technology applications, always keeping social welfare in mind" (ROBY, 1981 apud SANTOS, SCHNETZLER, 2010, p. 62).

When teaching is guided by interactions between Science-Technology-Society-Environment (STSE), it grants to individuals awareness about implications regarding science development. For example, "values of the scientific activities, methods of knowledge validation, relations with technology, society and techno-scientific system and its contributions to culture and society development" (ACEVEDO et al., 2005, p. 122-123).

For this reason, the in-service program for teachers is a challenge to be overcome, so we will be able to grant STSE in compulsory education in a continuous way.

Thus, it is extremely important to provide opportunities in university in order to teachers study their theoretical and methodological intakes, so they will be able to elaborate, plan and construct an educational environment that contemplates relationships between science, technology, society and environment.

Progress in STSE have given opportunity to rethink the teaching and learning process of teachers, allowing them to become aware and active professionals, regarding social researching about science.

Considering that, it is imperative that alternative pedagogical and didactical strategies be built up, reaching such level to awake in students the responsibilities to make decisions (MARTíNEZ, VILLAMIL, PENA, 2006).

In-service programs must provide pedagogical methods and practices to educators which take them to think over their role in compulsory education, because, articulating their values and conceptions may take them to understand that "science is a social practice, being susceptible to structural changes, variations and, undoubtedly, remaining linked to several other interests" (BAZZO, 1998, p. 167).

Therewith, there will be teachers ready to construct, with their students, scientific knowledge, promoting scientific and technological alphabetization, empowering them to make decisions with responsibility in the social context. 


\section{METHODOLOGICAL PROCEDURES}

This study was approved by the Ethics Committee of the Federal Technological University of Paraná (Opinion № 529.071). Therefore, meets the requirements of Resolution 466/2012 of the National Health Council for research involving human beings.

This study was carried out at the Federal Technological University of Paraná (UTFPR), Campus de Londrina. 12 students got involved as participants of the research, all of them from the specialization course in teaching and technology, as well as teachers from Basic Education of the state of Parana and from the county of Londrina. The investigation was conducted on the ScienceTechnology-Society classes.

A qualitative research was prioritized for this study, once it provided straight contact between the researcher and the situation investigated. It also favored conditions to understand, decode, explain and emphasize the multiplicity of educational field and school knowledge (LÜDKE, ANDRÉ, 1986).

It was adopted as a methodological strategy an action-research, for being a research strategy, which combines various methods and techniques of social research and also for establishing a collective, participative and active structure at the level of abstraction of information (THIOLLENT, 2005). To the author, this kind of research is necessary because in addition to being one of the ways of performing experiments under real situation, the researchers can consciously intervene in such a way to play an active role as a participant of the process, i.e., they can build knowledge, gain experience, contribute to the discussion and leverage the debate on issues approached.

To carry out the research it was required four stages, totaling a period of 16 hours of class. Firstly, it was explained the proposal of the study and invite students to participate. The interested students signed in the free consent, explained form (FCET). Then, aiming to know whether the participants had already heard of the STSE perspective, they were asked a question in order to check whether they knew the prospect Science-Technology-Society-Environment (STSE) applied to education.

After that, it was used a questionnaire with nine essay questions concerning to the initial and professional graduation, to the conceptions of science, technology, environment and the understandings of the STSE perspective for the teaching. Then, it was performed a dialogic reading of an article named "The sociological critique to of the traditional epistemological approaches and the exercise of scientific citizenship" (RIBEIRO, 2008).

Secondly, it was approached knowledge inherent to the origins of the STS movement through a dialogued exposure; its concept and unfolding were addressed. Following that a movie named "Ford: The Man and the Machine" was screened in order to reflect on the image of the technology in today's society, its benefits, risks and it's implicate actions for society and the environment.

Thirdly, the class started with the reading of an article of Bazzo, Linsingen, and Pereira (2003), which proposed the comprehension as well as the construction of knowledge inherent in 
the theoretical and methodological aspects involved in the development of the STSE perspective. Later, it was fostered the reading of chapters the books Campos (2010) and Freire (1987). The former conceptualizes the foundations on STS, education, STS in everyday life, in the curriculum, alphabetization and scientific and technological literacy, as well as in teaching from the STS perspective. The latter encourages the study of the main themes and its teaching methodology.

Fourthly, the participants gathered together in groups, selected and planned specific content contemplating the STSE perspective. Then, each group presented their teaching proposal of the scientific content via STSE perspective to basic education. At the end of the presentations, participants answered to two open questions, being the first question about the knowledge built through the STSE approach to the teaching and learning of scientific content, and the second question about the contribution to their pedagogical practice and to the scientific content planning from the perspective STS. The collected data were transcribed for analysis considering the process and not just the results.

The data analysis was carried out as per the Textual Discourse Analysis, presented in qualitative research to analyze the data as "[...] a process of unitarization in which the text is split into units of meaning" (MORAES, GALIAZZI, 2007, p. 16). According to the authors, Textual Discourse Analysis is comprised of an open methodology, investigative thinking, of a process of truths with deconstruction followed of reconstruction.

\section{ANALYSIS AND DISCUSSION OF DATA}

In this section, it is presented the profile of teachers and their major and teaching time experience, as per the graphs 1 and 2. After that, it is presented the analysis of some results got through the data collection instruments used during the research. The discussions of the results are based on the theoretical framework revisited.
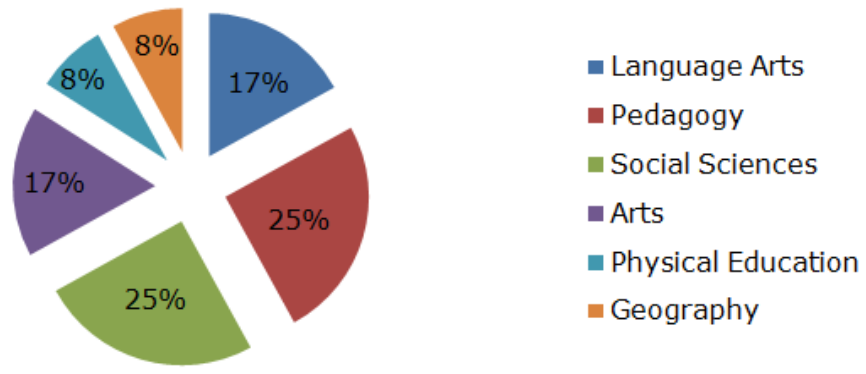

Chart 1: Performance and participant's formation

The results presented in chart 1 show that the interviewee students have different backgrounds, being three from the area of Social Science, what features $25 \%$ of the participants, two from the area of Language Arts (17\%), three from Pedagogy (25\%), two from Arts (17\%), one from Physical Education (8\%) and one from Geography (8\%). It is clear, therefore, that all of the participants are licensed. Once these professionals work in the education field, it is highlighted the importance of participants know and understand, even if badly, the concepts and implications of the STSE perspective. The fact that they present different professional graduation is a feature of the 
course in which they are enrolled, thus, from an interdisciplinary teaching proposal, brings together students from diverse backgrounds, characteristic that favored working with the STSE teaching perspective.

All participants involved in the research also reported being teaching in basic education, so in chart 2 it is shown the working experience time of each of the interviewee.
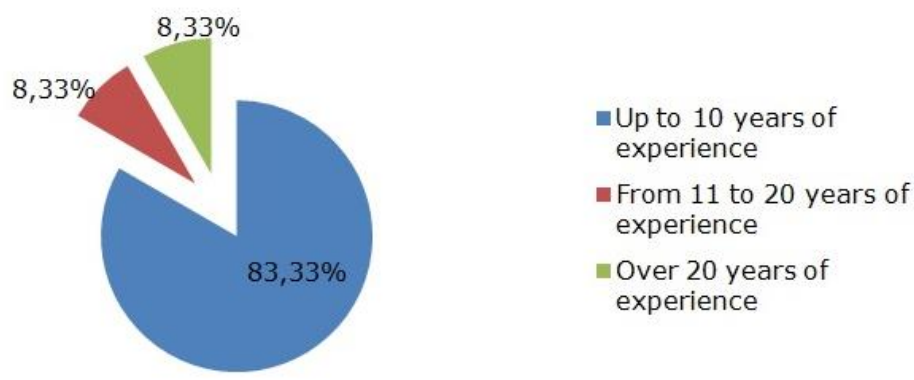

\section{Chart 2: Teaching Time Experience}

The results of chart 2 indicate that the time of graduation of most of the interviewee is recent, ie, $83.33 \%$ of them have up to 10 years of work. Only the interviewee from the area of Language Arts presents more than 20 years of teaching experience, which equates to $8.33 \%$ and an Arts teacher, who has been working since 2001 , which equates to $8.33 \%$, counting 13 years of experience.

After the information was organized in graphs 1 and 2, it is time for the analysis and discussion of the first question: "Have you ever heard the Science, Technology, Society and Environment perspective/approach (STSE) in education"? The answers got from teachers interviewed indicated that all of the participants were not aware of the term and its applications, as per the excerpts below:

No, I haven't got a clue.

No, not up until now.

No, I did not know anything about STSE.

No, I have never heard about it. This is the first time.

From the answers, it is clear the lack of knowledge of the interviewees regarding to the knowledge and objectives linked to the STSE teaching perspective. So that, it was provided time for the knowledge construction about the postulates of the STSE perspective, which allowed the investigated interviewees may be able to reflect on the approach applied to education. Such action is advocated by the Santos and Schnetzler (2010), as he says that teacher educators need to bring knowledge to students that lead them to participate actively in modern society, in the sense of seeking for alternative science and technology applications, within a view of social welfare.

After the construction of knowledge and the socialization of information of the scientific content covered by STSE perspective, the interviewees answered a questionnaire comprised of nine essay questions, from which, only two of them were analyzed regarding to the objectives of work, as follow: a ) "Describe what has been the knowledge built through the STSE approach to the 
teaching and learning of scientific content" and b) "In your opinion, what contributes to your pedagogical practice the scientific content planning from the perspective STSE"?

According to the answers about the knowledge built by teachers during the research, most of the interviewees realized the importance of adding other areas of study to promote the teaching and learning of scientific knowledge for each discipline from the perspective STSE, ie interdisciplinary, verified from the excerpts of the speech below:

The interdisciplinary provided by this STSE perspective is the key to this training.

The STSE approach broadens the horizons for the discussion of the content allowing a strong interaction with other disciplines to further improve the contents.

The importance of the STSE perspective for the teaching and learning is to build knowledge aiming to train the conscience of the students about current issues involving interdisciplinary perspectives, which a relevant social and environmental reality $[\ldots]$.

The quest for knowledge in order to build an interdisciplinary planning.

It expanded the ways of how to plan and put in practice the content. Always seeking partnerships with teachers from other areas [...].

The constant search for knowledge to plan an interdisciplinary way, a theme in many different forms.

The knowledge built form the critical ability that the person can use in discussing issues proposed and the graduation of feasible positions when faced with environmental/social/cultural/technological problems.

The STSE perspective aims to encompass the knowledge [...] enriching and making a student more critical and aware of everything. The Knowledge built was a greater awareness and concern with the scientific, technological advances in society and what are its impacts and damage to the environment [...].Think what will be the consequences for future generations [...].

Through the STSE approach, the knowledge built into the teaching and learning make active participants in society, or rather the awareness of the critical citizen, acting and interacting in society and in the environment and aware of their actions.

The answers also indicate that students reflected on the goals of the STSE perspective by revealing information like form critical and active citizens in society, participating subjects during teaching. According to Santos and Schnetzler (2010, p. 56) a study within a STSE perspective in teaching must contribute to "[...] the formation of critical citizens, who are able to make relevant decisions in society regarding scientific and technological aspects".

The teachers, participants of the research, learned that this perspective allows the insertion of several teaching alternatives, such as dialogue, contextualization through social issues, interdisciplinarity. In addition, active participation in the teaching-learning process is prioritized, which favors the development of the autonomy.

On the second question "In your opinion, what contributes to your teaching scientific content planning on the STSE perspective"? The teachers showed a more elaborated understanding regarding the STSE approach to the teaching because in the beginning of work, they affirmed not 
knowing the STSE approach. All of them answered positively, i.e. they realized the importance of a pedagogical practice based on the STSE relations, once, and according to them this perspective provides dynamic classes, interaction with other subjects, beginning from everyday themes, from students' context, the graduation of critical citizens, among something else, as it is shown below:

The contents based on the STSE perspective, the practice can become more dynamic, adding value to information, making interrelation of various disciplines and professionals.

Contributes to the strengthening of the content itself when we interact with other "issues" bringing timeliness or proposals that are in the "wave" of the moment approach is clearer and more attractive.

From the use of the STSE perspective the contribution will be for a successful development of a lesson, [...]. Considering that it seeks to address the science, technology, society and environment interconnected with the content of our everyday life, providing a better and effective learning, taking to a more reflective and critical student.

It will enrich the content, giving students opportunies to expand their knowledge, providing opportunities for active participation of both the student and the community (student's family) that also gets involved indirectly and also benefits from that.

On planning the scientific contents by the STSE perspective the classes start having a different customary approach. It is the training of a critical citizen, of a citizen who makes decisions, minimizing the negative impacts of attitudes, where you live in.

Under this context, teachers understood that for planning and developing the scientific knowledge of the disciplines, the teacher will have to move away from the traditional way of teaching and prioritize alternative methodologies, as well as the endless quest for knowledge not covered in their specific area of graduation. This fact is relevant to begin the demystification process around the concept that the knowledge can be fragmented and tight, ie, the knowledge must be understood in a broader way socially and historically.

\section{FINAL CONSIDERATIONS}

Through the data presented, it can be concluded that research herein promoted the continuing education of teachers through an innovative pedagogical and methodological knowledge in the CTSE perspective; since, the participants understood its importance to the school context, planned, developed and presented proposals of scientific knowledge, prioritizing this teaching perspective.

Another important result was the recognition of the participants regarding to the development of content through an interdisciplinary approach. Finally, it was realized how important it is to contribute to the continuing education of teachers of basic education to enable them having the opportunities to build knowledge inherent to the STSE perspective in order to contemplate it in their practice, breaking the traditional model of education, turning it the most significant, participatory, critical and consistent with the contemporary world education. 


\section{BIBLIOGRAPHY}

1. ACEVEDO, M. L. R. et al. Naturaleza de la ciência y educación científica para la participación ciudadana. Una revisión crítica. Revista Eureka sobre Enseñanza y Divulgación de Las Ciencias, [Madrid], v. 2, n. 2, p. 121-140, 2005.

2. AIKENHEAD, G. STS Education: a rose by any other name. In: A VISION for sciences education: responding to the work of Peter Fensham. 2003.

3. AKAHOSHI, L. H. An analysis of instructional materials with CTSA approach produced by chemistry teachers in a continuing education course. Master's Thesis. Institute of Chemistry, Faculty of Education. São Paulo: University of São Paulo, Brazil, 2012.

4. AULER, D. Interactions between science-technology-society in the training of science teachers. Thesis (Doctorate in Education - Natural Science Education). Florianópolis: Federal University of Santa Catarina, Brazil, 2002.

5. BAZZO, W. A. Science, technology and society: and the context of technological education. Florianópolis: UFSC, 1998.

6. BAZZO, W. A., LINSINGEN, I. V., PEREIRA, L. T. V. (Ed.). Introduction to CTS (science, technology and society. Madrid: OEI, 2003.

7. BRAZIL. The House of Representatives, LDB: Law of Guidelines and Bases of National Education, 5th Ed Brasília. DF: Documentation and Information Centre, 2010.

8. CAMPOS, F. R. G. Science, Technology and Society. Florianópolis: Publications IF-SC, 2010.

9. CEREZO, J. A. L. Science, technology and society: the state of the art in Europe and the United States. In: Santos, L. W et al. (Eds.). Science, technology and society: Challenge interaction. Londrina: lapar, 2002.

10. CHRISPINO, A. et al. The CTS area in Brazil seen as social network: where we learn? Ciênc. Educ., v. 19, n. 2, p. 455-479, 2013.

11. FIRME, R. N., AMARAL, E. M. R. Conceptions of teachers on science, technology, society and their interrelations: a preliminary study for the development of CTS approaches in the classroom. Ciênc. Educ., v. 14, n. 2, p. 251-269, 2008.

12. FREIRE, P. Pedagogy of the Oppressed. Rio de Janeiro: Continuum, 1987.

13. GARCÍA, I. M. G., CEREZO, A. L. J., LUJÁN, J. L. Science, Technology and Society: An Introduction to Social Studies of Science and Technology. Madrid: Tecnos, 1996.

14. GOUVÊA, G., LEAL, M. C. A comparative view of education in science, technology and society at school and at a science museum. Magazine Science and Education, v. 7, n. 1, p. 67-84, 2001.

15. KRASILCHIK, M. Teaching science to assume social responsibilities. Journal of Science Education, 14, 8-10, 1985.

16. KRASILCHIK, M. Science education and the training of citizens. In Open, 40, 55-60, 1988.

17. LÜDKE, M., ANDRÉ, M. E. D. Educational research: qualitative approaches. São Paulo: EPU, 1986. 
18. MARCONDES, M. E. R. et al. Instructional materials perspective CTSA: Analysis of didactic units produced by chemistry teachers in training, Research in Science Teaching, 14, 2, 281-298, 2009.

19. MARTÍNEZ, L. F., VILLAMIL, Y. M., PEÑA, D. C. Actitudes favorables hacia la química a partir del enfoque ciencia, tecnología, sociedad y ambiente (CTSA). In: Congresso Iberoamericano de Ciência, Tecnologia, Sociedade e Informação, 1., Cidade do México. Annals... Cidade do México: OEI, 2006.

20. MENEZES, P. H. D. et al. Insertion of the CTSA focus in basic education through a science fair. In: ENDIPE XVI: Meeting of National Curriculum and Teaching Practices. Campinas: Unicamp, Brazil, 2012.

21. MORAES, R., GALIAZZI, M. C. Discursive textual analysis. Ijuí: Unijuí, 2007.

22. MUENCHEN, C., AULER, D. Joints between the assumptions of the educator Paulo Freire and STS movement: Facing challenges in the context of adult education. In: VI ENPEC. Florianópolis, Brazil, 2007.

23. NUNES, A. O. Addressing the CTSA relations in chemistry teaching from the beliefs and attitudes of undergraduates: a formative experience in the northeastern hinterland. Dissertation (Master). Natal: University Federal do Rio Grande do Norte, Brazil, 2010.

24. RIBEIRO, E. A. The sociological critique of traditional epistemological approaches and practice of scientific citizenship, Acta Sci Soc Human Sci., v. 30, n. 1, p. 1-7, 2008.

25. RICARDO, E. C. CTSA Education: obstacles and potential for implementation in the school context, Science \& Education, 1, no special, 1-12, 2007.

26. SANTOS, W. L. P., MORTIMER, E. F. Decision making for social responsible action in science education, Science and Education, v. 7, n. 1, p. 95-110, 2001.

27. SANTOS, W. L. P., AULER, D. CTS and Science Education: Challenges, trends and research results. Brasília: UNB, Brazil, 2011.

28. SANTOS, W. L. P., SCHNETZLER, R. P. Education in Chemistry: commitment to citizenship. Ijuí: Unijuí, 2010.

29. SILVA, H. C. S. Articles of popular science and science teaching: conceptions of science, technology, society. Dissertation (Master) - College of Education, Campinas: State University of Campinas, Brazil, 2003.

30. SOLBES, J., VILCHES, A. Role of relationships between science, technology, society and environment education for citizenship, Science education, v. 22, n. 3, p. 337-348, 2004.

31. SOLBES, J., RÍOS, E. The CTSA relations in the teaching of Technology and Sciences: a proposal with results, electronics Magazine Science Education, v. 6, n. 1, p. 32-55, 2007.

32. STRIEDER, R. B. CTS approach in Science Education in Brazil: Directions and Prospects. Doctoral Thesis - Institute of Physics and School of Education, University of São Paulo, 2012.

33. TENREIRO-VIEIRA, C., VIEIRA, R. M. Construction of didactic and pedagogic practices guidance CTS: impact of a continuing education program of the primary school science teachers, Ciênc. Educ., v. 11, n. 2, p. 191-211, 2005.

34. THIOLLENT, M. Methodology of Action Research. São Paulo: Cortez, 2005. 
35. VASCONCELLOS, E. S. Approach to environmental issues by theme CTS: analysis of pedagogical practice in high school chemistry and activity propositions. Dissertation (Master) - Brasília: University of Brasília, Brazil, 2008.

36. VILCHES, A., PÉREZ, D. G. Educación para un nuevo orden socio-ambiental: Reflexiones acerca del futuro del Seminario Ibero-americano CTS. In: Seminário Ibero-americano CiênciaTecnologia-Sociedade no Ensino das Ciências, 2., Brasília, DF. Annals... Brasília, DF: [s.n.], Brazil, 2010.

37. VON LINSINGEN, I. Educational perspective CTS: aspects of a field in consolidation in Latin America, Science \& Education, v. 1, special number, p. 1-19, 2007.

38. VASCONCELLOS, E. S., SANTOS, W. L. P. Environmental education through CTSA theme: report and analysis experience in the classroom. In: International Conference on Chemical Teaching, 14, Curitiba. Annals... Curitiba, Brazil: Ed. da UFPR, 2008. 